\title{
Uterine giant cell carcinoma: a case report and review of the literature
}

\section{Uterin dev hücreli karsinom: olgu sunumu ve literatür sunumu}

\author{
(1) Hülya Ayık Aydın¹, (1) Hasan Aykut Tuncer1 , (1) Gülgün Erdoğan², (1) Tayup Şimşek1 \\ 1 Akdeniz University Faculty of Medicine, Department of Obstetrics and Gynecology, Division of Gynecologic Oncological Surgery, Antalya, Turkey \\ 2 Akdeniz University Faculty of Medicine, Department of Pathology, Division of Gynecopathology, Antalya, Turkey
}

\begin{abstract}
Endometrial carcinoma is the most common genital malignancy in women. Endometrioid type is the most common variant of endometrial carcinoma described in literature. Giant cell carcinoma is a rare, and infrequently reported variant of endometrial carcinoma. We present a 75-year-old patient admitted with vaginal bleeding. Transvaginal ultrasound revealed a 26×28 mm hypodense lesion without any adnexal pathology. The patient underwent total abdominal hysterectomy, bilateral salpingo-oophorectomy, and bilateral pelvic, and paraaortic lymph node dissection. The final histopathology report

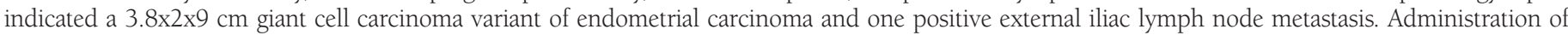
adjuvant carboplatin and paclitaxel chemotherapy was given. As far as we know, this is the fifteenth case reported in the English literature.
\end{abstract}

Keywords: Endometrial carcinoma, giant cell tumor, uterus

$\ddot{O} z$

Endometrial karsinom kadınlarda en sık genital malignitedir. Endometrioid tip literatürdeki en sık varyanttır. Dev hücreli karsinom nadir ve az rapor edilen bir varyanttır. Yetmiş beş yaşında vajinal kanama ile başvuran bir hastayı sunduk. Transvajinal ultrasonda 26x28 mm hipodens lezyon mevcuttu adneksiel patoloji yoktu. Hastaya total abdominal histerektomi bilateral salpingooferektomi ve bilateral pelvik ve paraaortik lenfadenektomi yapıldı. Final patolojide 3.8x2x9 cm dev hücreli uterin karsinom saptandı ve bir pozitif external iliak lenf nodu metastazı saptandı. Karboplatin ve paklitaksel kemoterapi planı yapıldı. İngilizce literatürde şimdiye kadar tanımlanmış 15. olgu olduğunu düşünmekteyiz

Anahtar Kelimeler: Endometrial karsinom, dev hücreli tümör, uterus

\section{Introduction}

Abnormal vaginal bleeding is the most common cause of referrals to gynecology outpatient clinics ${ }^{(1)}$. In women age 40-50 years, the endometrial cancer (EC) incidence was 13.6-24 in 100,000 women, and 87.3 in 100,000 women in the 70-74 years age group ${ }^{(2)}$. EC is the $4^{\text {th }}$ most common genital cancer in women, and endometrioid type accounts for $80 \%$ of all $\mathrm{ECs}^{(3)}$. Rare, and infrequently reported variants of EC include hepatoid carcinoma, glassy cell carcinoma, lymphoepithelioma-like carcinoma, adenocarcinoma with trophoblastic differentiation, and giant cell carcinoma (GCC)

(3). However, infrequent variants are under-reported in the English literature.

Nash and Stout ${ }^{(4)}$ described GCC in 1958 to define an aggressive cancer of the lung. GCC is a recently defined variant of EC. It is a unique and rarely described entity with only 14 cases reported in the literature to date ${ }^{(5-9)}$. Consequently, even though this tumor appears to have aggressive behavior in particular cases, the prognosis of GCC remains uncertain. Herein, we aimed to present a rare case of uterine GCC in a 75-year-old female.

\section{Case Report}

A 75-year-old G5P5 patient who had been postmenopausal for 23 years was admitted with symptoms of vaginal bleeding. The patient additionally had type $2 \mathrm{DM}$ and hypertension. A gynecologic examination revealed normal external genitalia, atrophic collum, intact adnexa, and free parametrium. Laboratory test results were as follows: CA125: $82 \mathrm{U} / \mathrm{mL}$, CA19-9: $42 \mathrm{U} / \mathrm{mL}$, and glycated hemoglobin (HbAlc): 11\%.

Address for Correspondence/Yazışma Adresi: Hülya Ayık Aydın

Akdeniz University Faculty of Medicine, Department of Obstetrics and Gynecology, Division of Gynecologic Oncological Surgery, Antalya, Turkey

Phone: +90 5077080245 E-mail: hulya_ayik@hotmail.com ORCID ID: orcid.org/0000-0002-3028-7247

Received/Geliș Tarihi: 09.08.2018 Accepted/Kabul Tarihi: 24.11.2018

${ }^{\oplus}$ Copyright 2019 by Turkish Society of Obstetrics and Gynecology

Turkish Journal of Obstetrics and Gynecology published by Galenos Publishing House 
Transvaginal ultrasound revealed linear endometrium, minimal intracavitary fluid, and a 26×28 mm hypodense lesion extending to the serosa with no adnexal pathology. Abdominal computed tomography revealed no pathology in the liver, spleen, kidney, small and large bowels, and ovarian loge. Endometrial cavity had a heterogeneous appearance, and no intra- and retro- peritoneal pathologic lymph node was detected (Figure 1).

Endometrial biopsy established the diagnosis of mixed EC [GCC (structural grade 3, and nuclear grade 3), and EC (structural grade 2, nuclear grade 2)]. Immunohistochemically, vimentin, and EMA produced widespread staining in the lesion (Figure 2). The histologic feature is bizarre multinucleated giant cells admixed with mononucleate tumor cells (Figures 3 and 4). Both tumors were stained with P53 focally, and ER dye stained areas of the EC. The tumor did not stain with P16, CEA, beta HCG and P63, desmin, MyoD1, CD10, caldesmon, and cyclinD1.

The results of cytokeratin staining were as follows: microscopic examination revealed large geographic tumor necrosis, multinuclear and mononuclear giant cells, and atypical mitosis. Therefore, endometrial neoplasms involving giant cells were considered and differential diagnosis included carcinoma, carcinosarcoma, leiomyosarcoma with osteoclast-like giant cells, undifferentiated sarcoma and choriocarcinoma with osteoclast-like giant cells. B-HCG was administered immunohistochemically and a negative reaction was observed. AEl/AE3 also showed a positive reaction in giant cells.

The patient underwent laparotomy, total abdominal hysterectomy, bilateral salpingo-oophorectomy, omental biopsy, and bilateral pelvic, and paraaortic lymph node dissection. The intraoperative frozen section result was reported as a tumor with a size of $3.8 \mathrm{~cm}$, and more than

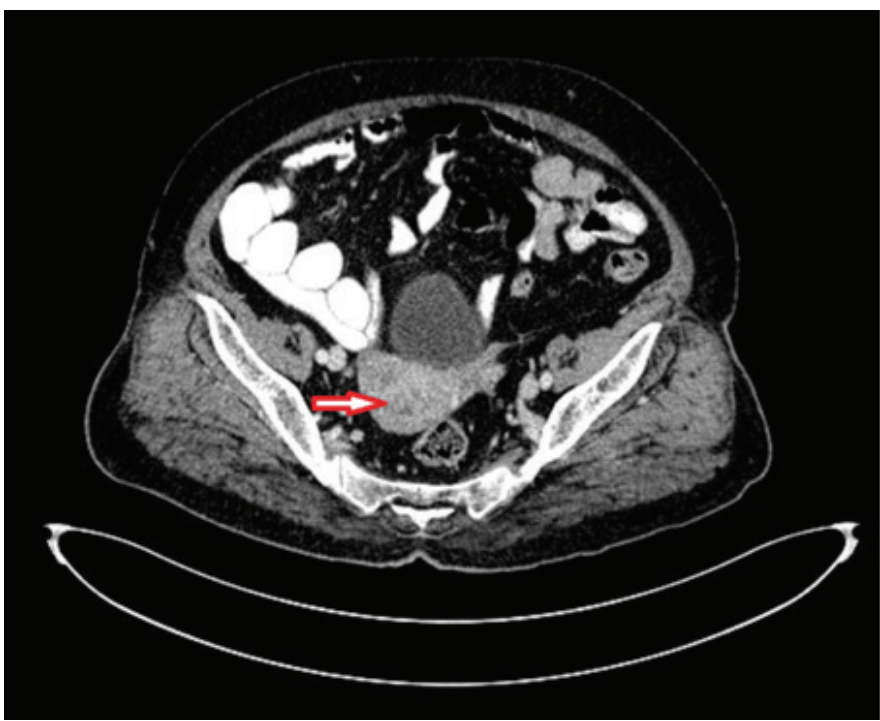

Figure 1. Abdominal computed tomography showing heterogeneous appearance in the endometrial cavity half of the myometrium was invaded. Postoperative followup of the patient was uneventful, so she was discharged. The final histopathology report indicated a $3.8 \times 2 \times 9 \mathrm{~cm}$ GCC variant of EC and one positive external iliac lymph node metastasis. Cytology of intraabdominal specimens was unremarkable. Administration of adjuvant carboplatin and paclitaxel chemotherapy was planned upon the decision of the multidisciplinary council

\section{Discussion}

This is a unique case presenting a GCC of the endometrium. GCC is a rare and aggressive endometrial variant that was first described in 1991 by Jones et al. ${ }^{(5)}$. As far as we know, this is the $15^{\text {th }}$ case reported in the English literature (Table 1).

Endometrial sampling should be performed on all women aged over 45 years who are suspected of having anovulatory uterine bleeding(6). Postmenopausal bleeding is the most common symptom of EC, which is detected in 10-15\% of cases $^{(7)}$. Therefore, patients with postmenopausal bleeding

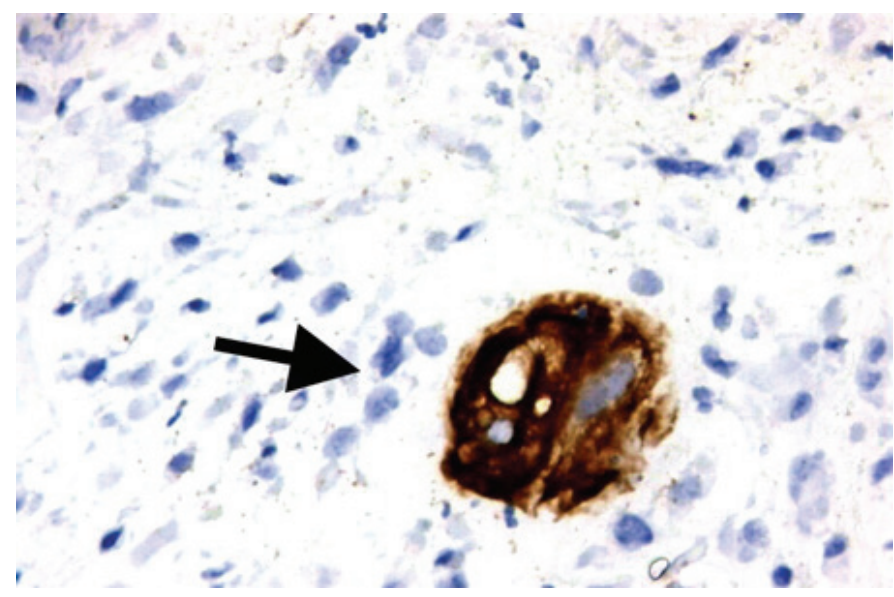

Figure 2. Immunohistochemistry PanCk positive staining of the tumor giant cells $(\mathrm{x} 400)$

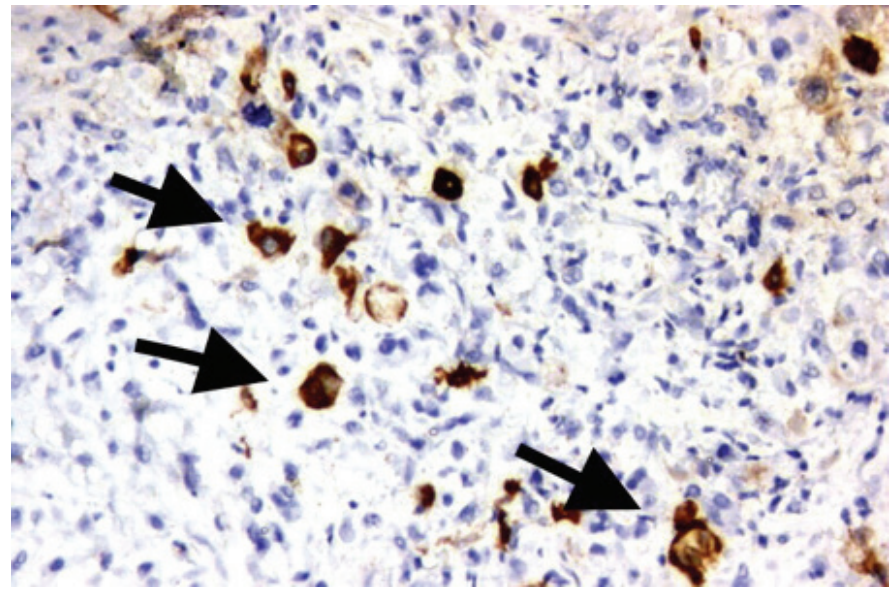

Figure 3. Immunohistochemistry PanCk positive staining of the tumor giant cells (x200) 


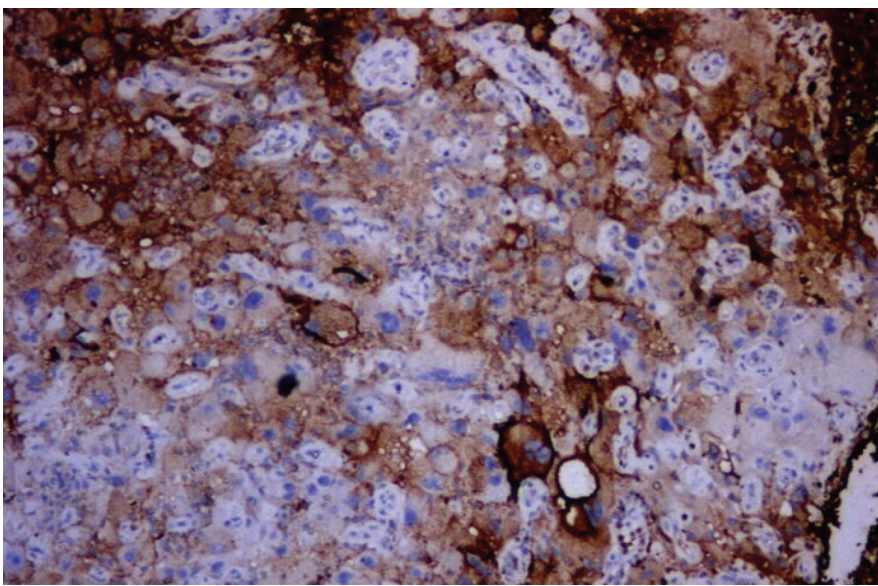

Figure 4. Immunohistochemistry vimentin positive staining of the tumor $(\mathrm{x} 200)$

should be evaluated in detail. The ages of all patients reported in the literature so far ranged from 43 to 85 years. Jones et $\mathrm{al}^{(5)}$. reported six patients with uterine GCC. All patients presented with vaginal bleeding. Occasional giant cells were positive for CK and EMA, whereas desmin and SMA were negative in all cases. Of the first six patients reported in the literature, four developed recurrence and three died in 3 years. Mulligan et $\mathrm{al}^{(8)}$. reported five patients, three of whom admitted with vaginal bleeding, one with anemia, and one with a pelvic mass. Of these five patients, one was diseasefree after 14 years, three patients showed no symptoms or signs related to the disease during the 15 to 32-month followup period, and one patient had metastasis to the lung four years after diagnosis. Bhattacharyya et al. reported a 70-yearold postmenopausal patient with symptoms of vaginal bleeding ${ }^{(9)}$. Johannesen et al. ${ }^{(10)}$ reported a 70-year-old woman with postmenopausal bleeding. Sharma et al. ${ }^{(11)}$ presented a 60 -year-old patient with vaginal bleeding. In the present case, a 75-year-old G5P5 postmenopausal patient admitted with symptoms of vaginal bleeding.

Endometrial carcinoma diagnosis should be verified by curettage and histopathologic examination of the tissue, as performed in the present case, also, when the final diagnosis can only be achieved in the surgical specimen ${ }^{(7)}$. Precise classification is mandated because the histologic type complemented by staging is crucial in the selection of treatment of choice ${ }^{(8,9)}$. The present case was categorized as International Federation of Gynecologists and Obstetricians stage $3 \mathrm{Cl}$. Accurate classification should be accomplished through histopathological examination, which is the gold standard.

The surgical treatment of EC is panhysterectomy with or without pelvic and paraaortic lymphadenectomy depending upon the grade of the tumor. Hormone therapy in EC is a well-established treatment modality for primary, metastatic, and recurrent cases. However, the role of hormone therapy in this rare and aggressive subtype of EC remains unstudied. To date, there are no data on the receptor (ER and PR) status of this tumor, positivity of which in our study could have a therapeutic implication.

Bhattacharyya et al. ${ }^{(9)}$, Johannesen et al. ${ }^{(10)}$, and Sharma et al. ${ }^{(11)}$ all reported total hysterectomy and bilateral salpingo oophorectomy as the treatment of choice in their patients who were reported to have been followed up in the outpatient clinic with no complaints. The present patient underwent total abdominal hysterectomy, bilateral salpingo oophorectomy, and bilateral pelvic and para-aortic lymphadenectomy.

\section{Conclusion}

In conclusion, GCC is a rare, and infrequently reported variant of EC diagnosed through histopathologic examinations of resected specimens. Awareness of this subtype of EC is essential to avoid misclassification of these cases due to a wide variety of differential diagnoses and poor prognosis.

Ethics

Ethics Committee Approval: The study was approved by the Institutional Review Board (No:562/08.08.2018). The study was performed in accordance with the ethical standards described in an appropriate version of the 1975 Declaration of Helsinki, as revised in 2000 .

Informed Consent: The patient's consent was obtained. Peer-review: Externally peer-reviewed.

\section{Authorship Contributions}

Surgical and Medical Practices: H.A.T., H.A.A., Concept: H.A.A., T.Ş., H.A.T., Design: T.Ş., Data Collection or Processing: H.A.A., Analysis or Interpretation: G.E., Literature Search: H.A.A., H.A.T., G.E., Writing: H.A.T.

Conflict of Interest: No conflict of interest was declared by the authors.

Financial Disclosure: The authors declared that this study received no financial support.

Uterine giant cell carcinoma: a case report and review of the literature

We present a 75-year-old patient was diagnosed as having giant cell uterine carcinoma.

The patient's consent was obtained. The study was approved by the Institutional Review Board (no:562 / date: 08.08.2018). The study was performed in accordance with the ethical standards described in an appropriate version of the 1975 Declaration of Helsinki, as revised in 2000

\section{References}

1. Coulter A, Noone A, Goldacre M. General practitioners' referrals to specialist outpatient clinics. I. Why general practitioners refer patients to specialist outpatient clinics. BMJ 1989;299:304-306.

2. Brenner PF. Differential diagnosis of abnormal uterine bleeding. Am J Obstet Gynecol 1996;175:766-9.

3. Rutgers JK. Update on pathology, staging and molecular pathology of endometrial (uterine corpus) adenocarcinoma. Future Oncol 2015;11:3207-18

4. Nash AD, Stout AP. Giant cell carcinoma of the lung; report of 5 cases. Cancer 1958;11:369-376. 
5. Jones MA, Young RH, Scully RE. Endometrial adenocarcinoma with a component of giant cell carcinoma. Int J Gynecol Pathol 1991;10:260-70.

6. ACOG Committee on Practice Bulletins-Gynecology. Practice bulletin no. 136: management of abnormal uterine bleeding associated with ovulatory dysfunction. Obstet Gynecol 2013;122:176-85.

7. Epstein E, Skoog L, Valentin L. Comparison of Endorette and dilatation and curettage for sampling of the endometrium in women with postmenopausal bleeding. Acta Obstet Gynecol Scand 2001;80:959-64.

8. Mulligan AM, Plotkin A, Rouzbahman M, Soslow RA, Gilks CB, Clarke BA. Endometrial giant cell carcinoma: A case series and review of the spectrum of endometrial neoplasms containing giant cells. Am J Surg Pathol 2010;34:1132-38.

9. Bhattacharyya A, Gon S, Bandyopadhyay G, Majumdar B, Gayen P. Giant cell carcinoma of endometrium: A rare clinical entity. Iran J Pathol 2012;7:197-202.

10. Johannesen E, Nguyen V. Malignant mixed mullerian tumor with an endometrioid adenocarcinoma with a component of giant cell carcinoma: a case report and literature review. J Clin Exp Pathol 2015;5:212.

11. Sharma P, Ahluwalia C, Kolte S, Mandal AK. Giant cell carcinoma of endometrium: A rare case report and review of literature. Clin Cancer Investig J 2016;5:79-82. 